\title{
PENGARUH KEPEMIMPINAN, MOTIVASI DAN KOMPENSASI TERHADAP KEPUASAN KERJA KARYAWAN DI PERUSAHAAN PT. MITRA KARUNIA INDAH
}

\author{
Riska Novialni ${ }^{1}$, Meita Pragiwani ${ }^{2}$ \\ ${ }^{1,2}$ Sekolah Tinggi Ilmu Ekonomi Indonesia \\ riskanovialni@gmail.com¹,ola_168@yahoo.com²
}

\begin{abstract}
ABSTRAK
Penelitian ini bertujuan untuk mengetahui hubungan antara Kepemimpinan, motivasi dan kompensasi terhadap kepusasan dari kerja karyawan di PT. Mitra Karunia Indah.

Populasi penelitian ini adalah karyawan yang bekerja pada kantor pusat (head office) PT. Mitra Karunia Indah dengan menggunakan google from sebagai media kuesioner. Metode pengambilan sampel menggunakan teknik Slovin dengan jumlah sampel 124 responden. Strategi yang digunakan dalam penelitian ini adalah strategi kuantitatif yang diukur dengan perhitungan Koefisien Determinasi (R2) parsial serta pengujian hipotesis uji t dengan SPSS 25.0 .

Hasil penelitian menunjukan bahwa, (1) Kepemimpinan secara parsial berpengaruh signifikan terhadap kepuasan kerja karyawan, (2) Motivasi secara parsial berpengaruh signifikan terhadap kepuasan kerja karyawan, (3) Kompensasi secara parsial berpengaruh signifikan terhadap Kepuasan Kerja
\end{abstract}

\section{Kata Kunci : Kepemimpinan, Motivasi, Kompensasi dan Kepuasan Kerja}

\section{ABSTRACT}

This study aims to determine the relationship between leadership, motivation and compensation for employee job satisfaction at PT. Mitra Karunia Indah.

The study population was employees who worked at the head office of PT. Mitra Karunia Indah using Google from as a media questionnaire. The sampling method using Slovin technique with a sample of 124 respondents. The strategy used in this study is a quantitative strategy that is measured by calculating the partial determination coefficient (R2) and testing the t-test hypothesis with SPSS 25.0.

The results showed that, (1) Leadership partially had a significant effect on employee job satisfaction, (2) Motivation partially had a significant effect on employee job satisfaction, (3) Compensation partially had a significant effect on Job Satisfaction.

\section{Keywords: Leadership, Motivation, Compensation and Job Satisfaction}

\section{PENDAHULUAN}

\section{Latar Belakang}

Terjadi menurunnya kinerja karyawan hal tersebut dikarenakan adanya faktor ketidak puasan dalam melaksanakan pekerjaan, seperti upah yang minim, lingkungan kerja yang tidak nyaman atau tidak sesuai, job description yang tidak sesuai dengan perjanjian awal. Dalam kepuasan kerja karyawan perusahaan harus lebih memperhatikan dengan serius agar pekerjaan yang 
memberikan hasil yang puas untuk perusahaan.

Seorang pemimpin memiliki peran yang sangat besar dalam pencapaian tujuan organisasi secara efektif dan efisien. Pemimpin yang menentukan bagaimana menggerakkan semua elemen yang ada dalam organisasi agar dapat mencapai tujuan yang telah ditentukan dan mendapatkan hasil yang optimal, seorang pemimpin harus dapat menciptakan suasana yang harmonis dan komunikasi yang baik dengan karyawan, sehingga dapat menciptakan kondisi kerja yang baik dimana karyawan bekerja diperusahaan akan mendapatkan kepuasaan kerja yang tinggi.

Pemimpin harus mampu menyesuaikan diri dengan keadaan yang ada di lingkungan pekerjaan. Kepemimpinan yang diterapkan dan disesuaikan dengan kebutuhan yang ada, situasi, dan kondisi yang terjadi dalam perusahaan. Menurut Fiedler dalam Thoa (2011:291) kepemimpinan yang dikombinasikan dengan situasi yang harus mampu menentukan keberhasilan pelasana pekerjaan. Kinerja karyawan dan kepuasan kerja karyawan juga akan dipengaruhi oleh kompensasi yang diterimanya.

Motivasi merupakan faktor yang sangat menentukan prestasi kerja karyawan. Perusahaan memberikan motivasi kepada karyawan melakukan training tentang pekerjaan agar karyawan mau dan rela mencurahkan tenaga dan pikiran yang dimiliki agar mengerjakan pekerjaan dengan baik dan sesuai target prosedur perusahaan. Jadi, apabila perusahaan memahami untuk memotivasi karyawan dan dapat mengatasinya maka perusahaan akan mendapatkan kepuasaan kerja yang diberikan karyawan dengan optimal dan sesuai dengan standar yang ditentukan perusahaan.
Pemberian kompensasi yang tepat akan berpengaruh positif terhadap kepuasan kerja karyawan. Adanya kompensasi berupa bonus, hadiah maupun penghargaan juga memberikan dampak positif bagi karyawan. Karyawan akan merasa termotivasi dan bersemangat dalam melaksanakan yang diberikan serta akan muncul dorongan karyawan untuk berprestasi dalam lingkungan kerja. Ada beberapa tujuan pemberian kompensasi anatar lain sebagai ikatan kerja yang sama antara perusahaan dengan karyawan, sebagai sarana untuk meningkatkan semangat dan motivasi karyawan, sebagai strategi perusahaan untuk mempertahankan karyawan atau pegawai yang berkualitas, sebagai penghargaan oleh perusahaan terhadap karyawan dan sebagainya.

Kepuasan dan ketidakpuasan yang dirasakan dengan karyawan dapat dilihat dari banyaknya jumlah absensi dan jumlah karyawan yang keluar dan masuk yang terjadi pada perusahaan tersebut. Semakin tinggi jumlah karyawan yang keluar maka dapat diasumsikan semakin rendah tingkat kepuasan yang dialami karyawan dalam bekerja. Tingginya jumlah karyawan yang keluar diperusahaan juga disebabkan oleh kebijakan perusahaan untuk mengurangi jumlah karyawan sehingga dapat terjadi efisiensi dalam proses pekerjaan.

PT. Mitra Karunia Indah adalah perusahaan yang bergerak dibidang Jasa Cleaning Service, perusahaan sudah berkembang dan mengeluarkan karyawan yang berkualitas dan mampu mengerjakan tugas tugas perusahaan dengan baik dan profesional. Sehingga perusahaan dapat mencapai tujuan keberhasilan dan sasaran perusahaan secara efektif, efisien dan ekonomis. Namun, ada beberapa masalah yang ditemukan peneliti pada beberapa karyawan PT. Mitra Karunia Indah.

Kondisi kerja para karyawan yang 
kurang baik juga adanya rendah tingkat kompensasi dan motivasi yang diberikan terhadap karyawan. Dapat dilihat dari jumlah kemangkiran karyawan yang semakin meningkat hal ini disebabkan karena tidak terpenuhinya jumlah kompensasi yang diharapkan oleh para karyawan,sehingga para karyawan lebih cenderung memilih bolos atau mangkir untuk melakukan pekerjaan sebagai freelance yang menghasilkan upah lebih besar. Selain itu kurangnya motivasi juga dapat menyebabkan jumlah peningkatan kemangkiran para karyawan.

\section{Tabel 1.2}

Total Jumlah Karyawan yang Masuk dan Keluar serta Tingkat

Labor Turn Over pada Perusahaan PT. Mitra Karunia Indah tahun 2013- 2017

\begin{tabular}{|c|c|c|c|c|c|c|c|}
\hline No & Tahun & $\begin{array}{c}\text { Jumlah } \\
\text { Karyawan awal } \\
\text { tahun }\end{array}$ & Masuk & Keluar & $\begin{array}{c}\text { Jumlah } \\
\text { Karyawan } \\
\text { akhir tahun }\end{array}$ & $\begin{array}{c}\text { LTO } \\
(\%)\end{array}$ & $\begin{array}{c}\text { Rata- } \\
\text { Rata }\end{array}$ \\
\hline 1 & 2013 & 100 & 20 & 5 & 115 & 4,65 & 107,5 \\
\hline 2 & 2014 & 115 & 13 & 3 & 125 & 2,5 & 120 \\
\hline 3 & 2015 & 125 & 10 & 5 & 130 & 3,92 & 127,5 \\
\hline 4 & 2016 & 130 & 7 & 2 & 135 & 1,51 & 132,5 \\
\hline 5 & 2017 & 135 & 15 & 2 & 145 & 1,43 & 140 \\
\hline
\end{tabular}

Berdasarkan data di atas, maka dapat dilihat tingkat perputaran karyawan selama lima tahun terakhir pada perusahaan PT. Mitra Karunia Indah dapat disimpulkan bahwa tingkat perputaran karyawan di perusahaan PT. Mitra Karunia Indah dari tahun ke tahun serta mengindikasikan mengalami kenaikan dan penurunan tingkat perputaran yang begitu signifikan dari tahun ketahun. Besarnya persentase dari tingkat absensi karyawan tersebut memberikan dengan atas ketidakpuasan yang dialami karyawan dalam bekerja pada perusahaan PT. Mitra Karunia Indah..

\section{Rumusan Masalah}

Berdasarkan latar belakang yang dikemukakan diatas, maka permasalahan yang ingin diangkat oleh penulis adalah :

1. Bagaimana pengaruh kepemimpinan terhadap kepuasan kerja karyawan PT. Mitra Karunia Indah?

2. Bagaimana pengaruh motivasi kerja terhadap kepuasan kerja karyawan PT. Mitra Karunia Indah?

3. Bagaimana pengaruh kompensasi terhadap kepuasan kerja karyawan PT. Mitra Karunia Indah?

\section{KAJIAN PUSTAKA}

Kepemimpinan berasal dari kata leadership. Kepemimpinan sangat mempengaruhi perkembangan dan kemajuan perusahaan. Pemimpin berperan aktif dalam membangun kerja sama tim di perusahaan, oleh karena itu kepemimpinan tidak bisa lepas dari struktur organisasi dalam perusahaan. Seorang pemimpin yang berkualitas mengarahkan fungsi manajemen perusahaan dengan baik, maka menjadi seorang pemimpin bukan hanya mengatur tetapi juga mengarahkan dan mengawasi.

Kepemimpinan adalah tanggung jawab, keteladanan, bukan kekuasaan semata. Didalam kepemimpinan, pemimpin harus santun, jujur dan adil memikul tanggung jawab dan memberi keteladanan kepada para bawahannya dalam menjalankan organisasi atau perusahaan (Wijaya \& Purnomolastu, 2015:3)Kepemimpinan adalah suatu norma perilaku yang digunakan oleh seseorang pada saat orang tersebut mencoba mempengaruhi perilaku orang lain atau bawahannya (Miftah Thoha,2010:49). 


\section{Definisi Motovasi Kerja}

Winardi, (2008: 1) motivasi berasal dari bahasa latin yaitu“Movere" yang berarti dorongan atau daya penggerak. Motivasi pada dasarnya merupakan proses yang tidak disadari.Jadi dalam tiap individu kebutuhan untuk memotivasi berbeda dari waktu ke waktu, kuncinya kebutuhan mana yang saat itu paling dominan. Motivasi adalah aktivitas pelaku sebagai energi untuk bangkit memenuhi kebutuhan dan tugas pekerjaan sesuai dengan tujuan yang di terapkan. (Fahmi Irham, 2016:25).Motivasi adalah segala sesuatu yang mendorong seseorang untuk melaksanakan tugasnya agar mencapai tujuan yang diinginkannya (David McClelland, 2013: 25).

1. Motivasi Instrinstik. Menurut Sobry Sutikno (2007) mengartikan Motivasi instrinstik sebagai motivasi yang timbul dalam diri individu sendiri tanpa ada paksaan dorongan orang lain, tetapi atas dasar kemauan sendiri. Dengan kata lain motivasi instrinstik merupakan motivasi yang muncul dari dalam diri seseorang tanpa memerlukan rangsangan dari luar. Adapun yang termasuk dari motivasi intrisik adalah sebagai berikut :

a. Perasaan ingin tahu akan sesuatu.

b. Berbagai jenis ambisi pribadi, seperti ingin menjadi pemimpin dalam sebuah organisasi, maka seseorang tersebutakan berusaha untuk menarik simpati calon pemilihnya.

c. Berbagai jenis kondisi belajar internal yang dimiliki individu seperti kematangan belajar dan kemampuan belajar

2. Motivasi Ekstrinstik. Menurut A.M. Sardiman (2009: 50) motivasi ekstrinstik adalah motif-motif yang aktif dan berfungsi karena adanya pengaruh dari luar. Motivasi ini merupakan dorongan yang ada pada diri seseorang untuk melakukan suatu tindakan atau perbuatan. Namun dorongan tersebut datang dari luar individu yang bersangkutan. Dengan kata lainmotivasi ekstrinstik merupakan motivasi yang timbul dari dalam diri seseorang akibat adanya pengaruh dari luar.

Kompensasi merupakan seluruh imbalan yang diterima karyawan atas jasa yang diserahkan karyawan kepada perusahaan atau dengan kata lain kompensasi merupakan semua penghargaan (materi dan non materi) yang diberikan oleh perusahaan atas jasa karyawan. Kompensasi salah satu faktor baik secara langsung atau tidak langsung mempengaruhi tinggi rendahnya kinerja karyawan oleh karena itu sudah semestinya pemberian kompensasi kepada karyawan perlu mendapat perhatian khusus dari pihak manajemen agar motivasi karyawan dapat dipertahankan dan kinerja karyawan yang diharapkan akan terus meningkat.

Dari beberapa keterangan diatas maka dapat disimpulkan bahwa bentuk- bentuk Kompensasi sebagai berikut :

1. Kompensasi Langsung, adalah penghargaan yang disebut gaji atau upah yang dibayar secara tetap berdasarkan tenggang waktu yang tetap (upah atau gaji diartikan sebagai harga untuk jasa-jasa yang telah diberikan oleh seseorang kepada orang lain).

2. Kompensasi Tidak Langsung, Adalah pemberian bagian keuntungan atau manfaat lainnya bagi para pekerja diluar gaji atau upah tetap, dapat berupa uang atau barang. Misalnya : THR, pemberian 
tunjangan kesehatan, cuti, liburan.

3. Fasilitas, Yang merupakan kenikmatan yang diberikan perusahaan sebagai bentuk perhatian perusahaan kepada karyawan.

4. Insentif, Adalah penghargaan yang diberikan untuk memotivasi para pekerja agar produktivitas kerjanya tinggi, sifatnya tidak tetap atau sewaktu-waktu.

Noe dalam Aulia dan Troena (2013: 4) menyatakan bahwa indikator kompensasi finansial terbagi menjadi empat, yaitu:

1. Upah dan gaji, yaitu Imbalan finansial yang dibayarkan kepada karyawan secara teratur seperti tahunan, caturwulan, bulanan dan mingguan.

2. Insentif, merupakan imbalan langsung yang dibayarkan kepada karyawan karena kinerjanya melebihi standar yang ditentukan. Dengan mengasumsikan bahwa uang dapat digunakan untuk mendorong karyawan bekerja lebih giat lagi maka mereka yang produktif lebih menyukai gajinya dibayarkan berdasarkan hasil kerja.

3. Tunjangan, yaitu imbalah tidak langsung yang diberikan kepada karyawan, biasanya mencakup asuransi kesehatan, cuti, pensiun, rencana pendidikan, dan rabat untuk produk-produk perusahaan.

Berkaitan dengan pengaruh gaya kepemimpinan, Kompensasi, dan Motivasi terhadap Kepuasan kerja karyawan, maka peneliti dapat memberikan beberapa hipotesis dalam penelitian ini, yaitu:
H1 : Diduga kepemimpinan berpengaruh terhadap kepuasan kerja karyawan.

H2 : Diduga Motivasi berpengaruh terhadap kepuasan kerja karyawan.

H3 : Diduga Kompensasi berpengaruh terhadap kepuasan kerja karyawan.

\section{Kerangka Konseptual Penelitian}

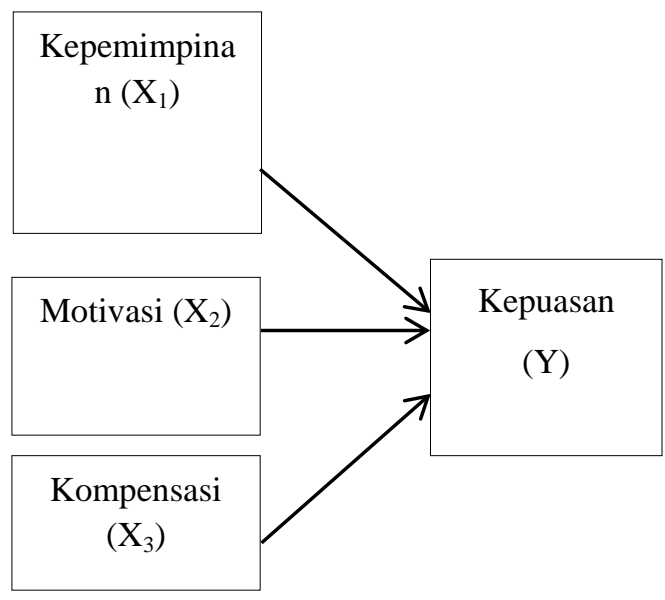

Gambar 2.1

Kerangka Konseptual

\section{METODE PENELITIAN}

Penelitian ini juga betujuan untuk mengetahui pengruh kepemimpinan, motivasi kerja dan kompensasi terhadap kepuasan kerja karyawan.

Metode penelitian yang digunakan untuk mendukung dalam penelitian ini adalah metode survei. Dengan demikian, penelitian survei adalah penelitian yang mengambil sampel dari satu populasi dan menggunakan kuesioner sebagai alat pengumpulan data yang pokok (Singarimbun, 2006).

populasi dalam penelitian ini dibagi menjadi 2 yaitu: populasi umum dan populasi sasaran. Populasi umum adalah 
totalitas semua nilai yang mungkin, hasil yang menghitung ataupun pengukuran, kuantitatif maupun kualitatif mengenai karakteritik tertentu dari semua anggota kumpulan yang lengkap dan jelas yang ingin mempelajari sifat-sifatnya (Sudjana 2010:6) jadi populasi umum pada penelitian ini yaitu 1000 karyawan, sedangkan populasi sasaran adalah bagian dari jumlah dan karakteristik yang dimiliki oleh populasi, populasi sasaran dalam penelitian ini berjumlah 150 karyawan.

Pembuatan kuesioner dilakukan secara online di google form, lalu mengirimkan informasi berupa link yang berisi kuesioner tersebut melalui chat di group dan personal pada aplikasi WhatsApp. Pengumpulan data didapatkan selama dua minggu dalam bulan februari sebanyak 109 sampel.

Metode pengumpulan data adalah teknik atau cara-cara yang dapat digunakan oleh peneliti untuk mengumpulkan data. Dalam penelitian ini, teknik pengumpulandata yang digunakan adalah menyebarkan kuesioner melalui media google form. Kuesioner merupakan teknik pengumpulan data yang dilakukan dengan cara memberi seperangkat pertanyaan atau pernyataan tertulis kepada responden untuk dijawab. (Sugiyono, 2017: 142).

Kuesioner diberikan kepada karyawan PT. Mitra Karunia Indah yang memenuhi kriteria. Hal ini dilakukan untuk menggali, mengumpulkan, menemukan informasi yang dibutuhkan atau berhubungan dengan penelitian.

\section{HASIL PENELITIAN DAN PEMBAHASAN \\ Hasil Penelitian \\ Analisis Deskriptif}

1. Hasil olah data dalam penelitian ini menunjukan bahwa ada pengaruh positif signifikan antar kepemimpinan terhadap kepuasan kerja karyawan secara parsial signifikan sebesar 0,0000 $<0,05$ (taraf signifikan). Hal ini berarti keberhasilan suatu organisasi baik sebagai keseluruhan maupun berbagai kelompok dalam suatu organisasi atau perusahaan tertentu sangat tergantung pada mutu kepemimpinan yang tepat dalam organisasi yang bersangkutan. Perilaku pemimpin merupakan salah satu faktor penting yang dapat mempengaruhi tingkat kepuasan kerja karyawan.

2. Hasil olah data dalam penelitian ini menunjukan bahwa ada pengaruh positif signifikan antara motivasi terhadap kepuasan kerja karyawan secara parsial dengan nilai signifikan sebesar $0,0000<0,05$ ( taraf signifikansi ). Hal ini berarti adanya keberhasilan pada motivasi yang diberikan antara pemimpin dan karyawan, maka akan iikuti oleh kenaikan kepuasan kerja karyawan di PT. Mitra Karunia Indah.

3. Hasil olah data dalam penelitian ini menunjukan bahwa ada pengaruh positif signifikan antara kompensasi yang diberikan terhadap kepuasan kerja karyawan secara parsial dengan nilai signifikan sebesar 0,0000 $<0,05$ ( taraf signifikansi ). Hal ini berarti kompensasi yang diberikan merupakan faktor yang harus diberikan kepada karyawan agar tercapainya kepuasan kerja, dengan memberikan kompensasi yang sesuai, maka akan dapat merasakan hasil kerja yang selama ini dikerjakan dan akan mampu merasakan kepuasan dalam bekerja di perusahaan PT. Mitra Karunia Indah.

\section{KESIMPULAN DAN SARAN}

1. Berdasarkan hasil penelitian variabel kepemimpinan dengan pertanyaan "Pimpinan memberikan pekerjaan sesuai SOP” memilliki nilai terendah. Dalam perusahaan memberikan pekerjaan yang sesuai dengan SOP dapat membantu kegiatan operasional perusahaan dan mempermudah karyawan dalam melaksanakan pekerjaannya. Dengan SOP, seluruh aktivitas perusahaan 
menjadi teratur dan tertib. Para pegawai tahu apa tugasnya, apa yang tidak boleh dilakukannya, dan apa yang harus dilakukannya. Dan untuk pertanyaan "Pimpinan mengembangkan cara-cara untuk mendorong kinerja karyawan" memiliki nilai tertinggi. Pimpinan harus lebih meningkatkan ide-idenya kembali untuk mendorong kinerja karyawan agar lebih baik dari sebelumnya.

2. Berdasarkan hasil pnelitian variabel motivasi dengan pertanyaan "Bekerja pada perusahaan ini akan menjamin saya dihari tua” memiliki nilai terendah. Sebaiknya perusahaan mampu memberikan fasilitas atau tunjangan jaminan hari tua kepada karyawan yang sudah bekerja lama pada perusahaan. Dan untuk pertanyaan "saya merasa tenang dalam bekerja karena tersedianya jaminan kesehatan dan asuransi kecelakaan dari perusahaan" memiliki nilai tertinggi. Perusahaan harus lebih meningkatkan kembali jaminan yang tersedia untuk seluruh karyawannya.

3. Berdasarkan hasil penelitian variabel kompensasi dengan pertanyaan "saya menerima uang transpot dari perusahaan” memiliki nilai terendah. Dalam melakukan pekerjaan diluar kantor atau bekerja dilapangan harusnya perusahaan memberikan uang transpot secara langsung tidak memberikan uang transpot secara rembes. Dan untuk pertanyaan "saya mendapatkan gaji setiap bulannya secara tepat waktu” memiliki nilai tertinggi. Untuk dalam hal ini perusahaan harus mempertahankan untuk memberi gaji setiap bulan tepat pada waktunya.

4. Berdasarkan variabel kepuasan kerja karyawan dengan pertanyaan "saya selalu menyikapi pekerjaan yang diberikan atasan dengan hal positif" memiliki nilai terendah. Dalam hal ini karyawan seharusnya selalu menerima dan menjalankan tanggung jawab pekerjaan yang ditugaskan oleh pimpinan dengan baik. Dan untuk pertanyaan "saya wajib mendukung visi dan misi perusahaan" memiliki nilai tertinggi. Seluruh karyawan harus mempertahankan visi dan misi dalam setiap melaksanakan pekerjaan yang diberikan oleh pimpinan.

\section{DAFTAR PUSTAKA}

AA. Anwar Prabu Mangkunegara. (2017). Manajemen Sumber Daya Manusia Perusahaan. Bandung : Rosda

A. M. Sardiman. (2009). Interaksi dan Motivasi Belajar Mengajar. Jakarta: PT Raja Grafindo Persada.

Arikunto, S. (2006). Metode Penelitian Kualitatif. Jakarta: Bumi Aksara

As’ad, Mohammad. (2009). Seri Ilmu Sumber Daya Manusia: Psikologi Industri, Edisi

IV. Yogyakarta: Liberty

Fahmi, Irham. (2016). Pengantar Manajemen Sumber Daya Manusia Konsep dan Kinerja. Jakarta: Mitra Wacana Media.

Fiedler, Fred E. (2011), Kepemimpinan dan Perilaku Organisasi Jakarta. Grafindo Persada

Hadari Nawawi (2005), Manajemen Sumber Daya Manusia untuk bisnis yang kompetitif, Cetakan Ke-4 Yogyakarta: Gajah Mada Univercity Press

Hasibuan, Melayu S.P. (2017). Manajemen Sumber Daya Manusia. Jakarta: Bumi Aksara

Hendriani, Sari, dkk (2014), Untuk mengetahui kepemimpinan dan kompensasi terhadap kepuasan kerja 
karyawan dan kinerja karyawan. Vol.12 No.1 ISSN: 1693-5241.

Ibnu, Sina (2016), Pengaruh gaya kepemimpinan, terhadap pekerjaan kepuasan karyawan dan motivasi terhadap kepuasan kerja karyawan dalam International Journal Of Economics and Finance Vol.8, No. $10 ; 2016$.

Nana, Sudjana.(2010). Dasar-dasar Proses Belajar, Sinar Baru Bandung.

Ni Made Nurcahyani, I.G.A Dewi Adnyani (2016) Pengaruh Kompensasi, Motivasi untuk mengetahui kepuasan kerja karyawan. Vol.5, 2016: 500- 532 ISSN: 2302-8912

Rizwan Saleem, Aseem Mahmood, Asif Mahmood (2013) Dampak motivasi kerja terhadap pekerjaan kepuasan dalam organisasi layanan telekomunikasi seluler di Pakistan. dalam International Journal of Bisiness and Management Vol.5, No. 11 November 2013

Sari Muis, dkk (2015), Pengaruh kepemimpinan, motivasi dan stress terhadap kepuasan kerja karyawan. Jurnal Analisis, Vol.1 No.1:87-93 ISSN 2303- 1001.

Thoha, Miftah. (2010). Kepemimpinan dalam Manajemen. Jakarta: PT Raja Grafindo Persada. Hal. 49.

Soekarso dan Putong Iskandar (2015), Kepemimpinan: Kajian Teoritis dan Praktis. Bogor: Mitra Wancana Media

Sofyandi \& Garniwa. (2007). Perilaku Organisasional, Yogyakarta: Graha ilmu.
Sri Widodo. (2016). Manajemen Sumber Daya Manusia: Teori, Perencanaan Strategi, Isu-isu Utama dan Globalisasi, Manggu Media, Bandung.

Sutikno, Sobry. (2009). Belajar dan Pembelajaran, Prospect. Bandung

Susanto, Yohanes. (2017). Peran Kepemimpinan dalam Pengelolaan Koperasi.Yogyakarta: Deepublish.

Stephen P. Robbins and Timothy A. Judge. (2009). Perilaku Organisasi Edisi 12 Buku 1. Terjemahan: Diana Angelica, Ria Cahyani dan Abdul Rosyid. Jakarta: Salemba Empat.

Wahyu Maulana (2018), Pengaruh kepemimpinan, kompensasi, dan promosi jabatan terhadap kepuasan kerja karyawan. Vol.3 No. 1 ISSN 1412-2936.

Widya Parimita, Siti Khoiriyah (2018), Untuk mengetahui deksripsi motivasi kerja terhadap kepuasan kerja karyawan. Vol. 9 No.1. e-ISSN: 2301-8313

Yesa Martha Vita, Endang Setyaningsih (2018), Kepemimpinan (leadership) dapat dikatakan sebagai cara pemimpin (leader), dalam mengarahkan sehingga menghasilkan kinerja karyawan yang maksimal., dalam International Journal of Business and ManagementVol.7 No.2. 